\title{
IMPLEMENTASI KEMAMPUAN KONEKSI MATEMATIS SISWA SMP MENGGUNAKAN PENDEKATAN PEMBELAJARAN CTL
}

\author{
Nicky Maya Sari ${ }^{1}$, Siti Yulianti ${ }^{2}$ \\ 1IKIP Siliwangi Bandung ${ }^{1,2}$ \\ Sarimay40@gmail.com ${ }^{1}$, Sitiyuliantiyuli6@gmail.com²
}

\begin{abstract}
Abstrak
Pada Penelitian ini dilatar belakangi dari pentingnya kemampuan koneksi matematis terutama di tingkat sekolah menengah pertama (SMP). Tujuan penelitian ini adalah untuk mengimplementasikan kemampuan koneksi matematis siswa menggunakan pendekatan pembelajaran Contextual Teaching And Learning (CTL). Metode penelitian yang digunakan adalah metode eksperimen di salah satu sekolah di Bandung Barat. Sedangkan sampel penelitiannya adalah siswa kelas VII yaitu kelas VII-C sebagai kelas eksperimen dengan pendekatan kontekstual sebanyak 22 siswa dan kelas VII-B sebagai kelas kontrol dengan pembelajaran yang biasa yang dilakukan sehari-hari disekolah. sebanyak 22 siswa. Instrumen terdiri tes perangkat pembelajaran untuk mengukur kemampuan koneksi matematis siswa. Tes dilakukan dua kali dengan soal yang sama yakni sebelum dan sesudah pembelajaran (pretestposttest). Berdasarkan perhitungan menggunakan Minitab 16 didapat hasil penelitian menunjukkan bahwa kemampuan koneksi matematis siswa yang menggunakan pendekatan pembelajaran Contextual Teaching And Learning (CTL) lebih baik dari pada dengan kemampuan koneksi matematis siswa yang menggunakan pembelajaran yang dilakukan sehari-hari oleh siswa disekolah. sebagian besar siswa memiliki interpretasi sikap baik terhadap pembelajaran Matematika dengan menggunakan pendekatan Contextual Teaching And Learning (CTL).
\end{abstract}

Kata Kunci: Implementasi, Kemampuan Koneksi Matematis, Pendekatan Pembelajaran CTL.

\begin{abstract}
This research is motivated by the importance of the ability of mathematical connections, especially at the junior high school level. The purpose of this study is to implement students' mathematical connection skills using the Contextual Teaching And Learning (CTL) learning approach. The research method used was an experimental method in one school in West Bandung. While the sample of the research is class VII students, class VII-C as an experimental class with a contextual approach of 22 students and class VII-B as a control class with the usual learning done everyday in school. as many as 22 students. The instrument consists of learning device tests to measure students' mathematical connection abilities. Tests are carried out twice with the same questions, namely before and after learning (pretest - posttest). Based on calculations using Minitab 16, the results of the study show that the mathematical connection ability of students who use the Contextual Teaching And Learning (CTL) learning approach is better than the mathematical connection ability of students who use learning done daily by students at school. most students have good attitude interpretations towards Mathematics learning using the Contextual Teaching And Learning (CTL) approach.

Keywords: Implementation, Mathematical Connection Ability, CTL Learning Approach
\end{abstract}




\section{PENDAHULUAN}

Matematika merupakan salah satu pelajaran yang penting dipelajari, karena Menurut Zhanty [1] pelajaran matematika memiliki kemampuan berpikir untuk siswa dengan mempelajari matematika siswa dapat berpikir secara sistematis, ilmiah, logika, kritis, dan kreativitas. Matematika suatu ilmu yang memiliki keterkaitan dengan topik-topik yang lainnya didalam kehidupan sehari-hari maupun dengan ilmu lainnya misalnya dengan ilmu teknologi, fisika, kimia, biologi dan masih banyak lagi, seperti yang dikatakan Rahayu [2] Matematika diajarkan disekolah diajarkan secara berkaitan dengan topik yang lainnya, topik ke topik yang lainya saling terlibat dan saling dilibatkan antara topik yang lainnya. Jadi dalam pembelajaran pemahaman siswa yang dipahami dalam satu topik dapat membantu dalam pemahaman ke topik yang lainnya, seperti halnya matematika merupakan ilmu yang memiliki keterkaitan dengan ilmu yang lainnya. jadi, siswa diharuskan bisa mengaitkan atau menghubungkan topik satu ke topik yang lainnya. Dalam ilmu matematika memiliki beberapa kemampuan salah satunya adalah Kemampuan koneksi matematis yang dapat mengaitkan atau menghubungkan topik yang satu dengan yang lainnya.

Namun pada kenyataannya beberapa Sekolah di Indonesia Pembelajaran disekolah masih berpusat dari guru dan sebagian besar siswa tidak aktip dalam pembelajaran. Siswa melakukan kegiatan belajar disekolah, karena belajar suatu kegiatan yang dilakukan sehari-hari bagi siswa disekolah. siswa belajar disekolah mempelajari banyak berbagai mata pelajaran salah satunya adalah matematika. Dilihat dari hasil diatas kemampuan koneksi matematis yang dimiliki siswa dalam pembelajaran masih rendah. Beberapa penyebab rendahnya kemampuan koneksi matematis siswa diantaranya menurut Putri dan Santosa [3] yaitu Penyebab rendahnya kemampuan koneksi matematis pada siswa dapat dilihat pada saat proses pembelajaran yang dilakukan dikelas. pada saat pembelajaran yang menjadi pusat informasi adalah guru dan siswa memiliki sifat pasif dalam penerimaan pelajaran yang disampaikan oleh guru, siswa tidak memiliki rasa tanggung jawab sehingga siswa menjadi malas dan tidak mau mengerjakan soal-soal yang diberikan guru, dan siswa hanya melakukan mencatat pelajaran yang disampaikan guru, membaca informasi yang diberikan oleh guru, dan menulis pelajaran yang sedang dibahas oleh guru tanpa memikirkan masalah yang ada dilingkungan sekitar sehingga menyebabkan tidak mau berlatih dalam menyelesaikan permasalahan kehidupan sehari-hari yang berhubungan denga konsep matematika.

Pada saat Pembelajaran yang dilakukan dengan adanya kemampuan koneksi Matematika membantu siswa dapat menghubungkan atau mengaitkan antara konsep-konsep yang diperoleh dalam bentuk yang nyata dan dalam konsep-konsep yang lainnya, sehingga siswa diberi makna yang baik untuk diri siswa dan untuk membangkitkan sikap minat belajar siswa terhadap matematika. Sebab siswa itu bukan hanya sekedar mengetahui namun juga siswa dapat paham dan mengerti suatu konsep matematika dalam kehidupan sehari-hari. Berdasarkan uraian di atas, pembelajaran Matematika disekolah perlu dilakukan usaha dalam meningkatkan kemampuan koneksi matematis siswa. Dalam pembelajaran disekolah memerlukan pendekatan pembelajaran matematika yang dapat membuat siswa paham dan mengerti terhadap mata pelajaran Matematika, dan memberikan gambaran tentang 
apa yang dipelajari yang dibuat secara mengkoneksi dengan kehidupan nyata. Oleh karena itu, pendekatan pembelajaran yang mampu meningkatkan kemampuan koneksi matematis siswa adalah dengan menggunakan pendekatan Contextual Teaching and Learning (CTL). Menurut Munawarah [4] pembelajaran Contextual Teaching and Learning (CTL) yaitu suatu konsep belajar yang membantu proses pembelajaran terhadap siswa seorang guru memberi suatu informasi yang mengaitkan antara materi yang diajarkannya dengan situasi dunia nyata dan mendorong siswa membuat hubungan antara pengetahuan yang dimilikinya dengan penerapan dalam kehidupan sehari-hari. Menurut Eka dan Ridwan [5] Langkahlangkah Pendekatan CTL sebagai berikut:

1) Konstruktivisme (constructivism)

2) Bertanya (questioning)

3) Inkuiri (inquiry)

4) Masyarakat Belajar (learning community)

5) Permodelan (modeling)

6) Refleksi (reflection)

7) Penilaian Autentik (authentic assessment)

Koneksi adalah suatu kemampuan yang dapat menghubungkan ilmu dari salah satu ilmu yang ada dengan kehidupan sehari-hari, kemampuan koneksi ini cocok dengan pendekatan pembelajaran Contextual Teaching and Learning (CTL) yang membuat siswa dapat mudah mengaitkan suatu konsep ke konsep yang lainnya dan Pada saat melakukan pembelajaran dengan adanya kemampuan koneksi merupakan kemampuan yang sangat penting untuk dimiliki oleh siswa, karena dengan adanya kemampuan koneksi dalam pembelajaran membuat siswa lebih mudah dalam memahami materi dan memudahkan siswa dalam menyelesaikan soal. Dalam kemampuan koneksi, kemampuan koneksi memiliki indikator menurut Herdiana \& Sumarmo [6] yaitu : (1) Memahami representasi ekivalen suatu konsep matematik (2) Mencari hubungan berbagai representasi konsep matematik (3) Memahami hubungan antar topik Matematika (4) Menerapkan Matematika dengan bidang lain atau dalam kehidupan sehari-hari (5) Mencari hubungan satu konsep dengan konsep yang lain dalam representasi ekuivalen (6) Menerapkan hubungan antar topik Matematika ke topik dengan ilmu lainnya.

Berdasarkan latar belakang pentingnya kemampuan koneksi matematis terutama di tingkat sekolah menengah pertama (SMP). Tujuan penelitian ini adalah untuk mengimplementasikan kemampuan koneksi matematis siswa menggunakan pendekatan pembelajaran Contextual Teaching and Learning (CTL).

\section{METODE}

Metode dalam penelitian ini menggunakan metode eksperimen (eksperiment) dengan sampel dua kelas yaitu kelas VII-C dan VII-B. Kelas VII-C diberikan perlakuan pembelajaran dengan menggunakan pendekatan pembelajaran Contextual Teaching and Learning (CTL) sebagai kelas eksperimen dan Kelas VIIB diberikan perilaku pembelajaran yang dilakukan sehari-hari oleh siswa disekolah sebagai kelas Kontrol. 
Pengukuran kemampuan koneksi matematis pada siswa dilakukan dua kali yaitu pada saat sebelum pembelajaran dan sesudah pembelajaran. Tes kemampuan awal atau pretes dilakukan yaitu untuk melihat kesetaraan kemampuan awal kedua kelas baik kelas yaitu eksperimen dan kontrol. Tes kemampuan akhir atau postes pada saat setelah kedua kelas eksperimen dan kontrol dilakukan yaitu untuk mengetahui bagaimana pengaruh pembelajaran kontekstual dan Pembelajaran biasa yang diberikan terhadap Implementasi kemampuan koneksi matematis dan melihat apakah ada perbedaan kemampuan yang signifikan diantara kedua kelas tersebut. Berdasarkan uraian di atas maka desain penelitiannya sebagai berikut :

Keterangan :

$$
\begin{array}{llll}
\text { A : } & \text { O } & \text { X } & \text { O } \\
\text { B : } & \text { O } & & \text { O }
\end{array}
$$

$\mathrm{A}=$ Kelas Eksperimen

$\mathrm{B}=$ Kelas Kontrol

$\mathrm{O}=$ Tes awal dan tes akhir

$\mathrm{X}=$ Pemberian perlakuan berupa pembelajaran Contextual Teaching and Learning (CTL)

Populasi yang diambil dari sekolah salah satu yang ada di Cihampelas Kabupaten Bandung Barat pada Sampel kelas VII yaitu dua kelas VII-C dan VIIB. Kelas VII-C sebanyak 22 orang dan kelas VII-B sebanyak 22 orang. Waktu penelitian ini dilakukan pada semester ganjil Tahun ajaran 2018/2019 pada tanggal 28 November 2019.

\section{HASIL DAN PEMBAHASAN}

Dari hasil data yang telah dikumpulkan, kemudian data tersebut diolah untuk mengetahui perbandingan peningkatan kemampuan koneksi matematis siswa dengan kelas yang menggunakan pembelajaran Contextual Teaching and Learning (CTL) lebih baik dari pada dengan kelas yang menggunakan pembelajaran yang dilakukan sehari-hari oleh siswa disekolah.

Maka untuk dapat mengetahui peningkatan kemampuan Koneksi matematis siswa, dilakukan perhitungan uji-t (Independent Sample t-test) untuk kedua sampel bebas menggunakan Minitab 16. Dilihat dari hasil output Minitab diperoleh TValue $=0,18$ dan $\mathrm{P}-$ Value $=0,860$ Pengujiannya adalah hipotesis $\mathrm{H} 0$ dan tandingan H1 dengan uji satu arah pada tingkat konfidensi $95 \%$ atau taraf signifikansi $\alpha=$ 0,05 dengan kriteria: jika P-Value $\leq \alpha$, Maka ditolak tolak H0. Jika P-Value $>\alpha$, maka diterima. Hasilnya terlihat $0,860 \leq 0,05$ bahwa nilai maka hipotesis $\mathrm{H} 0$ di tolak dan hipotesis $\mathrm{H} 1$ yang merupakan hipotesis penelitian diterima akan tetapi rata-rata skor N-Gain kelas eksperimen lebih baik dari pada kelas kontrol yaitu 2,87 dan kelas kontrol 2,41 maka dapat disimpulkan bahwa Implementasi kemampuan koneksi matematis siswa dengan menggunakan pembelajaran dengan pendekatan Contextual Teaching and Learning (CTL) secara signifikan lebih baik dari pada siswa yang menggunakan pembelajaran secara biasa yang dilakukan sehari-hari oleh siswa disekolah. 
Sesuai dengan tujuan penelitian ini, yaitu untuk mengetahui implementasi kemampuan koneksi matematis siswa melalui pendekatan pembelajaran Contextual Teaching and Learning (CTL) dengan pembelajaran yang biasa yang dilakukan sehari-hari oleh siswa disekolah. Maka melalui bagian ini dikemukakan beberapa pembahasan yang berkaitan dengan rumusan masalah penelitian dan pengujian hipotesis. Hasil pretes menunjukkan bahwa kemampuan koneksi matematis pada materi Himpunan antara kelas eksperimen maupun kelas kontrol masing adalah 67,57 dan 64,55 .

Hasil pengolahan data skor pretes kemampuan koneksi menghasilkan TValue dalam daerah penerimaan maka H0 diterima. Ini berarti tidak terdapat perbedaan yang signifikan antara kelas eksprimen maupun kelas kontrol pada kemampuan awal atau pretes dalam koneksi matematis siswa, dapat disimpulkan bahwa kemampuan awal atau pretes koneksi matematis siswa pada kedua kelas tersebut tidak berbeda sebelum diberi perlakuan dengan pendekatan pembelajaran Contextual Teaching and Learning (CTL). Berdasarkan hasil pretes tersebut kemampuan awal atau pretes dalam pembelajaran koneksi matematis siswa menunjukkan bahwa pembelajaran yang dilakukan tersebut membuat siswa sulit untuk memahami, menghubungkan dan mengaitkan dalam konsep maupun konsep ke konsep yang lainnya. Oleh karena itu, tugas seorang guru adalah harus bisa mengaitkan konsep matematika dengan mata pelajaran lainnya . Menurut NCTM [7] siswa dapat memperluas wawasan pengetahuan yang telah dimilikinya dan siswa memandang matematika itu ilmu yang bisa saling dikaitkan dengan ilmu yang lainnya karena matematika bukan materi yang berdiri sendiri.

Hasil postes menunjukkan bahwa kemampuan koneksi matematis siswa pada kelas eksprimen memperoleh rata-rata skor 85,33 dan kelas kontrol memperoleh rata-rata skor 77,00. Maka dari itu, dapat dikatakan bahwa setelah diberi perlakukan kedua kelas memiliki kemampuan yang berbeda secara signifikan. Hasil ini sejalan dengan hasil penelitian Yanirawati dkk [8] mengatakan bahwa dalam penelitian pada saat pembelajaran dengan dua kelas yang diberi pembelajaran yang berbeda ada perbedaan yang signifikan antara kelas eksprimen setelah dilakukan pembelajaran pendekatan Contextual Teaching and Learning (CTL) dan kelas kontrol menggunakan pembelajaran biasa yang dilakukan. Untuk lebih jelas melihat perbedaan peningkatan kemampuan koneksi matematis siswa.

Berdasarkan hasil wawancara dilakukan, siswa pada kelas eksprimen mempunyai kemampuan mengaitkan konsep Himpunan dan bukan Himpunan karena pada saat pembelajaran diberikan pendekatan Contextual Teaching and Learning (CTL) yang lebih baik dari pada kelas kontrol yang diberikan pembelajaran yang dilakukan sehari-hari oleh siswa disekolah. Dari hasil yang didapat dalam penelitian ini maka disimpulkan bahwa kemampuan koneksi matematis siswa melalaui pendekatan pembelajaran pendekatan Contextual Teaching and Learning (CTL) mengalami peningkatan secara signifikan. Hasil perolehan data tersebut memperlihatkan bahwa kemampuan koneksi matematis siswa melalui pendekatan pembelajaran pendekatan Contextual Teaching and Learning (CTL) lebih baik dari pada pembelajaran yang dilakukan sehari-hari oleh siswa disekolah. 
Menurut Hutagol [9] bahwa siswa yang belajarnya dengan pendekatan Contextual Teaching and Learning (CTL) hasil pembelajarannya lebih baik dari pada siswa yang belajarnya dengan pembelajaran biasa yang dilakukan dan Menurut Iramawati [10] menyimpulkan bahwa penerapan pembelajaran pendekatan Contextual Teaching and Learning (CTL) dapat meningkatkan hasil belajar siswa pada mata pelajaran yang lain juga yaitu kimia dan pembelajaran pendekatan Contextual Teaching and Learning (CTL) sekaligus dapat meningkatkan aktivitas belajar siswa. Oleh karena itu, dapat disimpulkan bahwa pembelajaran pendekatan Contextual Teaching and Learning (CTL) dapat meningkatkan kemampuan koneksi matematis siswa dibandingkan dengan menggunakan pembelajaran yang dilakukan sehari-hari oleh siswa disekolah.

Dari hasil diatas disebabkan pembelajaran pendekatan Contextual Teaching and Learning (CTL) memiliki tujuh komponen utama yang semua komponennya dapat menumbuhkan keterkaitan kemampuan koneksi matematis siswa. Satu diantara komponen pembelajaran pendekatan Contextual Teaching and Learning (CTL) yang dapat menumbuhkan keterkaitan kemampuan koneksi matematis siswa adalah komponen kontruktivisme. Misalnya, ketika guru mengajukan permasalahan kontesktual yang berhubungan dengan konsep Himpunan. Pada saat itu siswa berupaya untuk menemukan jawaban atas pertanyaan yang diberikan. Sebagian besar siswa saling berdiskusi dan bertanya antar sesamanya untuk menjawab pertanyaan tersebut. Hal ini mengisyarakatkan bahwa siswa tersebut dapat mengkontruksikan dan mengaitkan pengetahuannya sehingga siswa dapat menyelesaikan permasalahan yang diberikan.

\section{KESIMPULAN}

Implementasi kemampuan Koneksi matematis siswa menggunakan pembelajaran pendekatan Contextual Teaching and Learning (CTL) lebih baik dari pada Implementasi kemampuan Koneksi matematis siswa menggunakan pembelajaran yang dilakukan sehari-hari oleh siswa disekolah. Berdasarkan hasil penelitian, maka peneliti dapat menyarankan bagi guru bidang studi matematika, model pembelajaran dengan pendekatan Contextual Teaching and Learning (CTL) sebaiknya digunakan sebagai alternatif dalam pembelajaran matematika untuk meningkatkan kemampuan koneksi matematis siswa.

\section{DAFTAR RUJUKAN}

[1] Zanthy, S. L., (2016). Pengaruh Motivasi Belajar Ditinjau Dari Latar Belakang Pilihan Jurusan Terhadap Kemampuan Berpikir Kritis Mahasiswa Di Stkip Siliwangi Bandung. Jurnal Teori dan Riset matematika (TEOREMA) Vol. 1 No. 1, September 2016.

[2] Rahayu, D. V. (2009). Perbandingan Kemampuan Koneksi Matematis Siswa Antara Yang Menggunakan Model Pembelajaran Advance Organizer Dengan Pembelajaran Konvensional. Skripsi: STKIP Garut: Tidak diterbitkan.

[3] Putri, R. I., \& Santosa, R. H. (2015). Keefektifan Strategi React Ditinjau Dari Prestasi Belajar, Kemampuan Penyelesaian Masalah, Koneksi Matematis, Self Effecacy. Jurnal Riset Pendidikan Matematika Volume 2 - Nomor 2, November 2015, (262 - 272). [online]. Tersedia: http://journal.uny.ac.id/index.php/jrpm/index [26 November 2016].

[4] Munawarah. (2017). Pengembangan Perangkat Pembelajaran Matematika Dengan Menggunakan Pendekatan Kontekstual. MaPan : Jurnal Matematika dan Pembelajaran, 5 (2), 168-186.

[5] Eka, K, \& Ridwan, M. (2015). Penelitian Pendidikan Matematika. Bandung: Refika Aditama. 
[6] Herdiana, H., \& Sumarmo U. (2014). Penilaian Pembelajaran Matematika. Cimahi: PT Refika Aditama.

[7] NCTM. (2000). Principle Anda Standards For Schools Mathematics. Resto.VA.

[8] Yanirawati,dkk. (2012). Pembelajaran Dengan Pendekatan Kontekstual Disertai Tugas Peta Pikiran Untuk Meningkatkan Kemampuan Koneksi Matematika Siswa. Jurnal Pendidikan matematika, Vol 1, No 1, part 3 : Hal 1-7.

[9] Hutagol, K. (2013). Pembelajaran Kontekstual untuk Meningkatkan Kemampuan Representasi Matematis Siswa Sekolah Menengah Pertama. Bandung. Jurnal Ilmiah Vol 2, No.1, Februari 2013: Program Studi Matematika STKIP Siliwangi.

[10] Iramawati. (2010). Meningkatkan Hasil Belajar Kimia Melalui Penerapan Pembelajaran Kontekstual. Medan: Tesis. UNM. 